\title{
Foreign Labor Migration Causes and Impacts in Nepal
}

\author{
- Dr. Laxman Singh Kunwar*
}

\begin{abstract}
This paper reflects the situation of foreign labour migration of Nepalese People. Globally, foreign labour migration is in increasing trends. In Nepalese context also foreign labour migration is being more important for employment mainly among unemployed people and youths who entered in labour force market. The number of foreign labour migrants and share of remittance in terms of GDP has increased. This article is based on secondary sources of information. The Global Commission on International Migration (GCIM) describes the driving forces in international migration in terms of "3Ds" (development, demography and democracy). In one side foreign labour migration has contributed to reduce poverty level and in other the income gap among migrants and non-migrants been increased. In addition, due to mail domination in foreign labour migration the role of women has been changed in households and society. It has contributed women empowerment mainly in male labour migrant's households. Migration has occurred throughout history, and current trends certainly indicate that it will continue to increase in the future. The forces of globalization have created opportunities for greater integration of labour market globally.
\end{abstract}

Keywords: foreign labor migration, labour force, remittance, poverty, GDP

\section{Introduction}

Globally, the rise in migration of workers across countries, the economic and social wellbeing of migrants, their families and their communities has been increasing. Growth in the number of international migrants has been robust over the last two decades, reaching 281 million people living outside their country of origin in 2020, up from 173 million in 2000 and 221 million in 2010. Currently, international migrants represent about 3.6 percent of the world's population (UN DESA, 2020).

International labour migration has emerged as a major global issue that affects most nations on the international, regional and national policy agendas. Labour, migrant workers contribute to growth and development in their countries of employment. Many migrant workers, especially low-skilled workers, face exploitative working conditions and enjoy

*Dr. Kunwar is an Associate Professor of Population Studies, Patan Multiple Campus, TU, Nepal 
only limited human and labour rights (ILO, 2010). In addition, migrants are motivated by the quest for higher wages and better opportunities, responding to the demand for their skills abroad, but many others are forced to migrate because of famine, natural disasters, violent conflict, persecution or simply a lack of decent work in their home country. Migration in search of work has increasingly become a livelihood strategy for both women and men because of the lack of opportunities for full employment and decent work in many developing countries.

Women, increasingly migrating on their own and now accounting for almost half of all international migrants and face specific protection problems. According to the UNPD, global migration rates for women have remained high since the 1960s, both in terms of the total number of women migrants and in terms of their share of the world's migrant stock (UN, 2002). With rising barriers to cross-border labour mobility, the growth of irregular migration and the trafficking and smuggling of human beings constitute major challenges to the protection of human and labour rights. Migration for employment is an important part of the global agenda of current period (ILO, 2010). In 1994, the International Conference on Population and Development (ICPD) held in Cairo considered the need for a new migration regime. The programme of action adopted called on origin and destination countries to cooperate to protect the rights of migrants, reduce clandestine or irregular migration, and combat racism and xenophobia (UN, 1995). The emergence of migration at the top of the international policy agenda, issues and challenges of labour migration with a view to guiding ILO action (ILO, 2010).

In Nepal, formal labor migration begins in 1814-1816, after the Nepal-British India war. A total of 4,650 Nepalese youngsters were recruited to the British armed forces as a BritishGurkha regiment after the conclusion of the war and signing of the Treaty of Sugauli in 1816. Similarly, the migration of Nepalese people for other employment purposes, such as working in the tea states of Darjeeling and the forest of Assam, India, began in the second half of the 19th century. Economic migration to the Middle East from South Asia and other parts of the world was spurred on by the oil boom in the early 1970s. With the increase in migration of workers, remittance inflow into the country has been rising steadily. In the ten years between 2003/04 and 2013/14, remittance rose from NRs. 58.6 billion (USD 548 million) to NRs. 543.3 billion (USD 5.1 billion). Some of the major economic progress that the country has made in the past two decades such as reduction in poverty and higher literacy, despite the conflict, has been attributed to remittance inflows rather than structural changes or development efforts by the government (Sapkota, 2013). Data from Nepal Living Standard Survey 2010/11 shows that almost 92 percent of labor migrants are men. About 50 percent of these men are in the age group 15 to 29 years and another 38 percent 
are between 30 to 44 years. Hence, Nepal is losing a substantial fraction of its young male workers to foreign migration (DoFE, 2015).

On the basis of international labour migrant's destination it can be categorized into three main groups, the first group includes workers migrating to India, mostly to work as soldiers, security guards, porters and construction workers. India is the oldest and the most common destination for Nepalese migrants and migration to India is often seasonal, with some migrants returning home every year during growing seasons and for festivals. Formal labor migration to India started in the early 19th century when Nepalese workers joined the colonial British army through a treaty between the two governments (DoFE, 2015). Migration to India is facilitated by the proximity between the two countries, the low cost of migration and the open-border policy that allows citizens of both countries to travel and work across borders (Seddon, 2005). It has been difficult to keep track of the number of Nepalese migrants in India; while official sources report 1.5 million Nepalese migrants in India, the actual number could be as high as 2 to 3 million (NIDS, 2010).

The second group consists of workers going to the Middle East and East Asia. Migration to these destinations from Nepal started in the early nineties after the restoration of democracy when a series of policy reforms, such as issuing permits for foreign employment, trade liberalization, financial deregulation and privatization, were implemented by the government to transform the closed and centralized agrarian economy of Nepal to a marketoriented one (DoFE, 2015). Between 2008/09 and 2013/14, Malaysia received the highest number of workers from Nepal (40.9\%), followed by Saudi Arabia (22.9\%), Qatar (20.3 \%), United Arab Emirates (11.2 \%) and Kuwait (2.1\%); only 2.6 per centof Nepalese workers migrated to other destinations (DoFE, 2015).

The third group of migrants includes workers going to developed countries like the United Kingdom, Australia, the United States and Japan. Most of these migrants either migrate as students or decide to work at the destination after graduating, or get their educational degrees in Nepal but go to work in skilled-labor sector abroad. The average cost of migration including to keep track of the number of Nepalese migrants in India is difficult, while official sources report 1.5 million Nepalese migrants in India, but the actual number could be as high as to 2 to 3 million (NIDS, 2011).

These migrants usually come from wealthier families and they migrate with the hope of better economic opportunities and higher standard of living. This kind of migration has been rising in recent years and this loss of skilled labor could have serious implications for the long-term development of the country (Poudel, 2015). However, most of these migrants migrate permanently and are able to take their spouse and children with them. 
Migrant workers may also be classified according to skill levels. Although migrants from developing countries work in almost every job type, they tend to be concentrated at the bottom and top of the employment ladder. The majority are at the bottom of the ladder in low-wage and low-skilled jobs that tend to remain migrant jobs. They work in agriculture, mining, construction and a variety of service areas, such as hotels and catering, restaurants and domestic work. Women are strongly represented in these low-paid service jobs, and many women now migrate on their own to take on such work

\section{Objectives}

Globally, foreign labour migration is in increasing trends and in Nepalese context it has been also a key social and economic concern at local, regional and national level. Therefore, the main objectives of this paper to describe the causes and impacts of Nepalese foreign labour migrants.

\section{Data and Method}

This article is descriptive in nature and entirely based on secondary sources of information.

\section{Discussions and Findings}

This section highlights the causes and impacts of foreign labour migration of Nepalese people. There are various causes and impacts related to Nepalese foreign labour migrants but this paper is concentrated to discuss only some major causes and impacts.

\subsection{Causes of Foreign Labour Migration from Nepal}

Migration from Nepal is mainly motivated by poverty and lack of economic opportunities at home. Out of the 400,000 youths that enter the labor market every year, more than 200,000 go overseas (Kharel, 2011). In 2008, though the official unemployment rate was only 2.1 percent, youth unemployment (age 15 to 29) was 19.2 percent and the rate of labor underutilization was 30 percent (NLFS, 2008). Additionally, the political environment, characterized by repeated strikes, closures and an investment-unfriendly setting, has driven the youth out of the country. The outflow of migrants was especially high during the war years, as many left the country to avoid being recruited into the war and to be able to find stable income source to support their families (DoFE, 2015). Given the poor economic and political conditions at home, many Nepalese households have been relying increasingly on migration to maintain their livelihoods. The oil industry boom of the 1970s in the Middle East along with the East Asian industrialization has made destinations such as Saudi Arabia, Qatar, United Arab Emirates, Kuwait, Malaysia, Hong Kong, Singapore, Brunei, Japan and South Korea attractive to Nepalese workers (DoFE, 2015). Also, the expectation of relatively higher wages in these destinations (compared to Nepal or India) may have 
encouraged migration from Nepal to these destinations. Sometimes returnees contribute to optimistic expectations about the earning potential at the destination by painting a rosier picture of their experience as migrants to feel more successful than those who haven't migrated (Prasai, 2005). Hence, migrants often find themselves overestimating their ability to send remittance, and end up extending their stay or migrating repeatedly (Castaneda, 2013). In addition to these factors, government regulations, migrant networks and social pressures to migrate also affect decisions to migrate. The Nepalese government has been focusing on promoting foreign employment by identifying potential foreign markets, establishing temporary working programs and training and exporting Nepalese workers in order to address domestic unemployment (Chapagain, 2013). Migration is a selfperpetuating process and as connections to migrants settled in destination countries increase and knowledge about foreign employment increases, more people rely on community-based networks to get to their destinations (Casteneda, 2013). Such networks have been central to encouraging migration from Nepal, as previous and current migrants pave way for prospective migrants by sharing their knowledge and experiences about the destination, strengthening migrant networks and increasing familiarity with the process and prospects of foreign migration (DoFE, 2015).

After the April 2015 earthquake, the outflow of migrants fell sharply as many migrants returned home or cancelled their plans to migrate to be with their families. The destruction left by the quake has created an increase in demand for construction jobs and development projects within the country, the inability of the government to use development funds efficiently and initiate the process of reconstruction has pushed workers towards foreign migration (Sijapati, 2015). The Global Commission on International Migration (GCIM) describes the driving forces in international migration in terms of "3Ds": development, demography and democracy (GCIM, 2005). Widening disparities in income, wealth, human rights and security across countries serve as push factors towards migration.

Nepal ranks among the poorest countries in the world. The country's economy is largely agrarian, with 73.9 per centof the employed population working in agriculture. However, agriculture in Nepal is mostly subsistence in nature, and the sector suffers from low productivity due to lack of infrastructure and high dependence on rainfall. Agriculture only contributes 33 percent to the country's GDP, and almost 80 percent of the country's population under poverty line is engaged in agriculture sector (Khanal, 2012). The low returns from farming have pushed workers to find alternative forms of employment. Even among those employed, 81 percent are in a vulnerable position working temporary jobs with no job security, and the labor underutilization rate due to skills mismatch, time-related underemployment and inadequate earnings is over 30 percent (ILO, 2010). The country's 
economic woes are political problems, including an unstable government, inefficient administrative system and the wreckage left by the decade-long civil war. Nepal was mostly under absolute monarchy until 1990. In 1990, amid increasing pressures to end the ban on forming political parties, large scale reforms were implemented to establish a system of constitutional monarchy where power was shared between the king and the political parties. Unfortunately, this new system turned out to be a setting for institutionalization of corruption, and continuous conflicts among the political parties led to poor governance (Sharma, 2006).

The Maoist party of Nepal emerged under this setting and started a war in 1996 from the rural areas of the country with the goal of fighting inequality and replacing Nepal's constitutional monarchy with communist republic (Sharma, 2006). After years of conflict between the government and the Maoist rebels, resulting in a loss of over 17,000 lives, a ceasefire was agreed in 2006 with the integration of the Maoists into the government. In 2008, monarchy was abolished and Nepal was declared a Federal Democratic Republic. The ruinous effects of the war have weakened Nepal's social well-being and hindered its potential for growth. The conflict arguably hit women and children the hardest as genderbased violence rose sharply during the war and many women and children got recruited into the Maoist army (Shakya, 2009). By 2001, the year when the war was most intense, almost NRs. 4 billion (USD 37.4 million) had been transferred from development to military expenditures (Kumar, 2003). The destruction of infrastructure and deterioration of business environment during the war resulted in an overall slowdown of economic activities. There are various causes of international migration, the causes vary from one person to another, one household to another as well as from one community to another. Broadly, the Global Commission on International Migration (GCIM) describes the driving forces in international migration in terms of "3Ds" (development, demography and democracy).

\subsection{Impacts of Foreign Labour Migration:}

The impacts of migration may depend on migrant destinations, as the nature of migration as well as the amount of remittance sent varies by destination. While migration within Nepal and to India is circular in nature with the migrants returning home more often, migrants in Gulf and South East Asia return home less often (Maharjan, 2012).

Labour migration has the potential to serve as an engine of growth and development for all parties involved destination countries, origin countries and migrant workers themselves. In destination countries, migration has rejuvenated workforces, rendered many traditional sectors like agriculture and services economically viable, promoted entrepreneurship, supported social security and welfare schemes, and satisfied the demand for skills in emerging high-tech industries. In the developing regions from which most migrants come, 
the positive contributions of migration are reflected in high remittance flows and the transfer of investment, technology and critical skills through return migration and connections with transnational communities or diasporas (GCIM, 2005).

Although globalization trends have facilitated the movement of goods, services and capital across borders, their impact on the cross-border movement of people and labour remains much more restricted, regulated by a complex web of immigration laws and policies that uphold the principle of state sovereignty (WCSDG, 2004). Economic indicators of globalization exports, foreign direct investment (FDI) and financial integration have expanded rapidly since the mid1980s. Yet globalization has had important implications for international labour migration, acting as both a "push" and a "pull" factor. It has facilitated linkages between international labour markets through vast improvements in information and communications technology (ICT). The demand for high technical skills has expanded opportunities for the mobility of skilled labour.

The receipt of remittance is often cited as the biggest positive impact of migration from Nepal. Between 2003/04 and 2010/11, the percentage of Nepalese households receiving remittance increased from 31.9 to 55.8. During the same time, the total remittance flow into the country rose from USD 547 million to USD 2.4 billion, and it reached USD 5.1 billion in 2013/14. Actual remittance could be higher than these estimates since remittance are often sent informally via hand or through the hundi system. The figure below shows the changes in economic growth in Nepal with the increasing inflow of remittance between 1999 and 2014. Remittance inflow directly affects both the micro and macro-economic circumstances of a country. At the household level, remittance directly enter the income stream and improve the standard of living by lifting budget constraints and increasing consumption. Of the total remittance received in Nepal in 2010/11, 78.9 percent was used on consumption, 7.1 percent on loan repayment, 4.5 percent on purchasing property, 3.5 percent on education, 2.4 per centon capital formation and the remaining 3 percent on other purposes (DOFE, 2015).

Studies on the impact of remittance in Nepal show that remittance have contributed to a decline in poverty levels (Leon-Gonzalez, 2012). At the macro-level, the inflow of remittance has added to Nepal's foreign exchange reserves and helped maintain the balance of payments (NIDS, 2011). Also, remittance is a more reliable source of foreign funds for the economy than FDI or aid. Migrants send money home so their families can meet their consumption needs (Ratha, 2007). The increase in consumption at household level through remittance receipt could contribute to growth through multiplier impacts, as increased consumption encourages domestic production. This effect, where increased domestic demand is fulfilled through imports instead of increase in domestic production, may bring 
no real benefits to the economy as higher imports hurt growth (El-Sakka, 1997). The foreign labor employment and remittance thereof reduces poverty. The logic behind it is that poor works as the labourer and the remittance goes directly to the poor household. The role of remittance in the economy and poverty reduction was claimed first by the Nepal Living Standards Survey (2004). It showed that the poverty declined from 42 percent in 1995/96 to 31 percent in 2003/04 and to percent in 2011. This decline is attributed the decline to the increasing flow of the remittance. During this period, nothing such spectacular happened in the country to attribute this poverty reduction. Investment, employment and economy were not growing during that period due to the armed conflict in the country (CBS, 2012)

The inflow of remittance in Nepal has contributed to currency appreciation leading to a loss of competitiveness in export sector and a rise in trade deficit (Sapkota, 2013). Remittance inflows in Nepal may have also contributed to increasing inequality; between 1995/96 and 2004/05 the Gini coefficient for Nepal rose from 0.34 to 0.41 (Acharya and Leon-Gonzalez, 2012). The poorest of the poor stay behind because of their inability to afford migration costs, the poor usually migrate internally or to India because of the low cost of migration to these destinations and send some remittance home. The relatively well-off, who go to countries in East Asia or Middle East, are able to earn relatively high income and send more remittance to their home. And, the rich, who migrate to developed countries, earn the highest level of income and are able to send even more remittance home (Gurung, 2012).

The outflow of the active labor force, both skilled and unskilled, could have eroded Nepal's productivity and hindered its growth if the value that migrants would have created had they stayed home is higher than the value of remittance sent (Taylor, 1999). The dependence on migration has made the economy of Nepal vulnerable to the labor market conditions at destination countries (ILO, 2010). In addition to these economic impacts, men's migration has several implications on the non-economic aspects of everyday life and the socio-cultural context at the origin. Separation of families as well as changes in household structure and gender composition in the community could influence social norms. In Nepal Hindu women are not allowed to perform funeral rites; however, in some of the villages in Syangja and Rolpa women have taken up these roles in the absence on men. Also, social remittance, in the form of transfer of knowledge and culture from the destination, could change cultural attitudes at home (Levitt, 1998).

The direct impact of migration of men is a change in the gender division of labor. As men leave their homes and fields to work at destinations abroad, responsibilities of the women left behind transform. Also, men's migration brings changes in the labor market conditions and the socio-economic structures at the origin country and influences women's 
participation in market work. Studies on impacts of men's migration on women's work often point to factors such as family structure, economic status, gender norms on women's physical mobility and the restrictions they face in entering the labor market as being vital to understanding women's market participation. When men migrate, women's domestic responsibilities are likely to increase as they compensate for any contribution in subsistence farming, home management or childcare previously made by the migrant. The increase in workload may be especially severe in agricultural households, where women replace male labor in the fields. Women in nuclear households may have to shoulder the entire burden of household work while responsibilities may be shared more evenly among family members in extended households. Men's migration creates shortages of labor supply; women enter the labor market especially if the existing barriers to entry start to disappear or if there is an increase in wages in the domestic market. Hence, men's migration could affect women's work within the household as well as their participation in market work.

Male-dominated migration is a common feature among most South Asian countries because of the prevalence of male breadwinner and female homemaker ideology, cultural restrictions on women's mobility in public spaces and, in some cases, restrictions placed by the government. The gendered nature of labor demand at the destination country, with many of the jobs in West Asia, Southeast Asia and East Asia being in 'male' sectors like construction, security, driving and manufacturing, has also contributed to the gender disparity in migration from South Asia (Piper, 2009).

Diasporas contribute to the development of their countries of origin through the promotion of foreign investment, trade, access to technology and financial inclusion. However, according to projections by the World Bank, the COVID-19 pandemic may reduce the volume of remittance sent to low-and middle-income countries from USD 548 billion in 2019 to USD 470 billion in 2021, a decline of USD 78 billion or 14 percent. The loss has affected the livelihoods of millions of migrants and their families, stalling progress in achieving the Sustainable Development Goals (WB, 2021).

\section{Conclusions}

Migration has occurred throughout history, and current trends certainly indicate that it will continue to increase in the future. While the forces of globalization have created opportunities for greater integration of labour markets, a complex web of national immigration laws and border controls has restricted the mobility of people across borders. Migrants contribute to the development of destination countries and also support the economy at home by sending remittance to their families. Foreign labor migration is often seen as a savior, especially for workers from developing countries where problems such as poverty, unemployment, inequality and conflict are prevalent. Yet growing disparities in 
wealth, incomes, human security, human rights and demographic trends across countries are all exerting upward pressure on migration. Every year, many millions of young men and women enter the labour force in developing countries like Nepal, where jobs are not created fast enough to absorb them. The impact of demographic trends in the form of population decline and ageing is being felt most profoundly in advanced destination countries, where scarcities of labour are emerging in many sectors. The shrinking of the labour force in these countries has generated a demand for workers in many sectors of the economy, particularly in services, which has been met to a significant extent by migrants. New technologies also allow more people to acquire the information they need to access the global labour market. The increased importance of labour migration seeking employment, the rise in temporary migration schemes, and the growth in numbers of migrants in irregular status pose challenges for the international community with important implications for the governance and regulation of labour migration and the protection of migrant workers' rights. An encouraging international trend is an increasing recognition of the positive contributions of labour migration to countries of origin and destination, as well as to migrants themselves.

\section{References:}

Acharya, C.P. \& Leon-Gonzalez, R. (2012). The Impact of Remittance on Poverty and Inequality: A Micro-Simulation Study for Nepal (National Graduate Institute for Policy Studies, Discussion Paper: 11-26). Retrieved from GRIPS website: http://www.grips.ac.jp/r-center/wpcontent/uploads/11-26.pdf

Castaneda, E. (2013). Living in Limbo: Transnational Households, Remittance and Development. International Migration, 51, 13 - 35.

Central Bureau of Statistics (2012). National Population and Housing Census 2011 (National Report), (Kathmandu: Central Bureau of Statistics).

Central Bureau of Statistics (2008). Nepal Labour force Survey (Kathmandu: Central Bureau of Statistics, National Planning Commission).

Department of Foreign Employment (DOFE) (2015). Labour Migration for Employment: A Status Report for Nepal: 2014/2015 (Kathmandu: Ministry Labour and Employment).

El-Sakka, M.I. (1997). Migration Remittance: Policy Options for Host and Origin Countries. (Project No. CC023, Final Report). Kuwait University.

Global Commission on International Migration (GCIM) (2005). International Migration, Remittance and Development: Myths and Facts (Geneva: GCIM)

Gurung, Y.B. (2012). Migration from Rural Nepal: A Social Exclusion Framework. Himalaya, the Journal of Association for Nepal and Himalayan Studies, (31) 1, Article 12.

International Labour Migration (ILO) (2010). World Work Report from one Crisis to Next? (Geneva: ILO).

Kharel, P. (2011, December). Remittance as Development Resource: The Experience of Nepal. In Asia-Pacific Regional Meeting on 'Implementing the Istanbul Programme of Action', ESCAP, Bangkok (pp. 14-16).

Kumar, D. (2003). Consequences of the Militarized Conflict and the Cost of Violence in Nepal. Center for Nepal and Asian Studies Journal, 30 (2). 
Levitt, P. (1998). Social Remittance: Migration Driven Local-Level Forms of Cultural Diffusion. The International Migration Review, 32(4), 926 - 948.

Nepal Institute of Development Studies (NIDS) (2010). Nepal Migration Year Book 2010. (Kathmandu: Nepal Institute of development Studies).

Nepal Institute of Development Studies (NIDS). 2011. Nepal Migration Yearbook 2010. NIDS and South Asia Regional Coordination Office Swiss-National Centre of Competence in Research (NCCR) North-South, Kathmandu, Nepal.

Piper, N. (2009). Gender and Labor Migration in Asia. Report on Gender and Labor Migration in Asia. (Geneva: International Organization on Migration).

PoudelKP (2015). Abandoned Agricultural Land in Mid-Hills of Nepal (Kathmandu: Forest Action Nepal and International Union for Conservation if Nature)

Prasai, S.R. (2005). Transnational Migration-Development Nexus and the Capability Approach: Reframing the Linkages. (Doctoral Dissertation). University of Illinois, Urbana-Champaign.

Ratha, D. (2007a February 6-7). Leveraging Remittance for Development. Paper presented at the Second Plenary meeting of the Leading Group on Solidarity Levies to Fund Development, Oslo. Retrieved from the World Bank website: http://siteresources.worldbank.org/INTPROSPECTS/Resources/3349341110315015165/LeveragingRemittanceForDevelopment.pdf

Sapkota, C. (2013). Remittance in Nepal: Boon or Bane? Journal of Development Studies, 49(10), 1316- 1331. (Manila: Asian Development Bank).

Seddon D. (2005), Nepal's Dependence on Exporting Labour. Country Profiles. Available: http://www.migrationinformation.org/Pro files/display.cfm?id=277.

Shakya, A. (2009). Social Impact of Armed Conflict in Nepal: Cause and Impact. Social Inclusion Research Fund, Nepal.

Sharma, K. (2006). Political Economy of Civil War in Nepal. World Development, 34(7), 1237 1253.

Sijapati, B. (2015). Women’s Labor Migration from Asia and the Pacific: Opportunities and Challenges. Migration Policy Institute. Retrieved from IOM website: http://publications.iom.int/system/files/pdf/mpi_issue12.pdf.

Taylor, J. E. (1999). The New Economics of Labour Migration and the Role of Remittance in the Migration Process. International Migration, 37 (1), 63 - 88.

United Nations (2002). International Migration Report: 2002 New York: United Nations)

United Nations Economic and Social Affairs (UN DESA) (2020). International Migration 2020 (New York: United Nation Organization).

United Nations Organization (1995). International Conference on Population and Development (New York: United Nation Organization).

World Bank (2011). Leveraging Economic Migration for Development: A briefing for World Bank Board (Washington DC: The World Bank Group).

World Bank (2021). Defying Predictions, Remittance flows Remains Strong during COVID-19 Crisis, press release, May 2021 (Washington, DC: world Bank)

World Commission on Social Dimension of Globalization (2004). A fair globalization: Creating opportunities for all. (Geneva: World Commission on the Social Dimension of Globalization and International Labour Office). 